\title{
A Note from the Outgoing Editor and an Introduction to the New Editor
}

\section{Frank Trovato ${ }^{1}$}

Published online: 11 March 2019

(C) Springer Nature Switzerland AG 2019

The first issue of Canadian Studies in Population was published in 1974 by the Population Research Laboratory at the University of Alberta. That year, the global population had surpassed 4 billion. With rates of natural increase fluctuating around $2 \%$, the planet was passing through a period of unprecedented population growth. At that time, a number of important works appeared, warning humanity of the potentially disastrous consequences of rapid growth on earth's natural systems and resources, a message emphatically emphasized by the influential books of Meadows and colleagues, The Limits to Growth (1972), and of Paul Ehrlich's 1968 bestseller, The Population Bomb. It was in this context of intense scholarly concern in population matters that the idea of a Canadian journal devoted to demographic research emerged. Parameswara Krishnan of the Sociology Department at the University of Alberta was the driving force behind the creation of Canadian Studies in Population. Serving as its first editor, Professor Krishnan successfully engaged the cooperation and assistance of the Canadian Population Society - a professional association devoted to the study and promotion of population research and knowledge dissemination - and the Population Research Laboratory at the University of Alberta, to make Canadian Studies in Population the official journal of the Association. Since its inaugural issue in 1974, 45 volumes have been published, comprising a broad range of Canadian and international research. Following Dr. Krishnan's editorship, a number of scholars, including myself, have edited this journal: Professors George Jarvis, Herbert Northcott, and Wayne McVey Jr.

Canadian Studies in Population could not have achieved success as an important Canadian scholarly venue for demographic research without the significant financial support from the Social Sciences and Humanities Research Council of Canada. On behalf of previous editors, I thank the Council for its support. Many thanks also to the Sociology Department at the University of Alberta and the Canadian Population Society for their collegial support. I also wish to thank the Society of Edmonton

Frank Trovato

ftrovato@ualberta.ca

1 Department of Sociology, University of Alberta, Edmonton, Canada 
Demographers and all former colleagues of the Population Research Laboratory for their valuable assistance.

The move of Canadian Studies in Population to Springer Nature publishers represents a significant turning point for the journal. Credit for this important development goes to Sara Dorow, Chair, Sociology Department, University of Alberta and Michael Haan, President of the Canadian Population Society. Sara and Michael worked diligently with Springer to secure the best possible arrangements for the journal and the new editor.

I am pleased to welcome Professor Simona Bignami as the new editor of Canadian Studies in Population. Dr. Bignami is an Associate Professor in the Department of Demography at the Université de Montréal. She obtained her doctorate in demography at the University of Pennsylvania, following a master's degree at the London School of Economics and Political Sciences. Her research interests span a number of intersecting demographic areas including indicators of population health, aboriginal demography, demography of developing countries, HIV/AIDS, family dynamics, social and economic determinants of health, and longitudinal survey data collection and analysis.

Professor Bignami is currently the director of the Research Group on Aboriginal Demography at the Université de Montréal. She is well connected to the Canadian and international demographic communities. She has presented her research at professional meetings of the Canadian Population Society, the Federation of Canadian Demographers, the Association des démographes du Québec, and the Population Association of America. She serves on the Executive Board of the Association des démographes du Québec and is a continuing member of the Center for Population Dynamics of McGill University. As part of her involvement with the Center, she has organized ad-hoc workshops on different subjects in collaboration with the Inter-University Center for Social Statistics, Statistics Canada, and the Institut de la statistique du Québec. Dr. Bignami maintains strong ties and collaborations with British and American population scholars. In the past five years, she has been a co-investigator on a large U.S. National Institute for Health funded project to study demographic and social epidemiological conditions in rural Senegal.

The transition of Canadian Studies in Population to Springer Nature will certainly enhance the journal's growth and prominence as an international venue for demographic research. Under Dr. Bignami's editorial leadership and the expert management of Springer, the journal will continue to prosper, building on the dedicated work of past editors. 